International Journal of Linguistics, Literature and Translation

ISSN: 2617-0299 (Online); ISSN: 2708-0099 (Print)

DOI: 10.32996/ijltt

Journal Homepage: www.al-kindipublisher.com/index.php/ijltt

\title{
The Analysis of Critical Discourse Analysis in the Speeches of Nadiem Makariem and Muhadjir Effendy at Teacher's Day
}

\author{
Rosi Wahyuni' 8 (D) $\triangle$ and Kastam Syamsi² 8(D) \\ ${ }^{12}$ Universitas Negeri Yogyakarta, Yogyakarta, Indonesia \\ $\triangle$ Corresponding Author: Rosi Wahyuni, E-mail: rosiwahyuni.2019@student.uny.ac.id
}

ARTICLE INFORMATION

Received: May 04, 2021

Accepted: June 10, 2021

Volume: 4

Issue: 6

DOI: $10.32996 /$ ijllt.2021.4.6.29

\section{KEYWORDS}

Critical Discourse Analysis, Speech, Language Used

\section{ABSTRACT}

This research aims to find out the critical discourse analysis in the text of speeches from Nadiem Makarim and Muhadjir Effendy. The speech was chosen because it is one of the objects in Critical Discourse Analysis (CDA). Critical Discourse Analysis (CDA) is an approach to analyse the relationship between language, ideology, and power. This research used the descriptive qualitative method. The researcher uses the three-dimensional framework by Norman Fairclough in analysing the data of Critical Discourse Analysis (CDA). In presenting and analyzing the data, the researchers used qualitative data analysis theory from Miles and Huberman (1994) in Gani (2011), consisting of data reduction, data display or representation, and conclusion drawing or verification. The result of this study shows that both the script of speeches from Nadiem Makarim and Muhadjir Effendy have micro, mezzo, and macro-level related to the framework of Norman Fairclough. The language used in both of the speeches is a standard language, but in the speech of Nadiem Makarim used more creative language that can touch the millennial generations, while in the speech of Muhadjir was the usual words that can make the audiences bored.

\section{Introduction}

A language is a tool for communication used by human beings to communicate with others in daily life. Saussure in Hasibuan (2018) views that language has an important role in structuring and creating both ideology and reality of society.

In everyday life, there are two ways of using language, which is directly and indirectly. Directly is a spoken language that means that the language users have no mediator in using it. For example, it is face to face conversation with people. While indirectly is a written language means that there is something that can be a bridge between the language users. The written language users can use certain devices, such as SMS (Short Message Service), letters, TV commercials, et cetera. The language use through direct or indirect, can be in the form of public speaking since public speaking has become a necessity in many professions. At this time, many professions demand the ability for good public speaking. Public speaking shows a person's conceptual framework, future concept, and amazing ideas.

One kind of public speaking activity is a speech, usually in the form of formal speech performed by a leader or important people to show their opinion, important events, or ideas that need to be discussed. Speech has many functions, such as to make a conductive situation where one person is needed to do a speech and give a positive feeling to be heard by the audience. There are some examples of speech, like graduation speech, religious speech, president and the staffs' official speech, oration, and leadership speech.

Speech is one of the objects in Critical Discourse Analysis (CDA), which aims to examine the relationship between language, ideology, and power (Brown, 1983). Through the use of language, it connects to its ideology and power as well. Language is used to convince, persuade, enlighten, inform, share and promise, which means that language links to the people's heart no

\section{K C AL-KINDI CENTER \\ R D FOR RESEARCH AND DEVELOPMENT}

Your gateway to world-class research

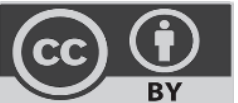

Published by Al-Kindi Center for Research and Development, London, United Kingdom. Copyright (c) the author(s). This open access article is distributed under a Creative Commons Attribution (CC-BY) 4.0 license 
matter what. Language and politics are inseparable because language is an essential tool in politics. Language helps people know how language is used by people who wish to procure power, exercise power, and keep the power themselves.

Power is an abstract idea, but it influences our lives. Politics relate to the power in making a decision, controlling resources, the people's behaviour, and values. While ideology, according to Dijk (2006), an idea is a fundamental belief acquired and sometimes changed through a relatively stable period of life.

The researcher chose the speeches of Nadiem Makarim and Muhadjir Effendy because the researcher wants to know what language used by both Makarim and Effendy, how their messages affect the listeners what they feel after hearing sentences from Makarim and Effendy. Through the language used, they make ideas about their power so that the researcher undertakes an analytical framework to study the relationship between the language used using Critical Discourse Analysis (CDA). In this research, the researcher used the three-dimensional framework by Fairclough.

From the explanation above, the researcher made this research to find out the following questions: 1) What are the micro, mezzo, and macro-level found in the speeches of Nadiem Makarim and Muhadjir Effendy? and 2) What is the language used in the speeches of Nadiem Makarim and Muhadjir Effendy?

\section{Literature Review}

Critical Discourse Analysis (CDA) in the above is to study the connection of language, ideology, and power; is an interdisciplinary approach used to study discourse which sees language as a form of social practice and focuses on the way both social and political domination are produced by text and talk (Priatmoko, 2013). CDA has become a special approach to investigate language, discourse, and communication of text and talk. Besides, CDA is a type of discourse analytical research that studies the way social power abuse, dominance, and inequality are set, reconstructed, rebelled in a text and talk of social and political context (Van Dijk, 1985).

Darma (2009) defines CDA as a process of deciphering a text in social reality done by someone who has a specific aim to get what he or she is desired. Therefore, it can be said that critical discourse analysis is applied to criticize the relationship between language and social-political news.

There are some characteristics of critical discourse analysis based on Eriyanto (2011). They are action, context, history, power, and ideology. Action is viewing discourse in two ways: discourse aims to impact, debate, persuade, et cetera and discourse is something that is showed consciously or controlled.

Context relates to how discourse is made and understood in a certain context like someone communicate with whom and why, who the audiences are, what the situation is, through what medium, and the relationship between the participants is. In contrast, history is always the time or event of the discourse. Power is something natural and neutral which is a form of power struggle (Putra \& Triyono, 2018). The last is an ideology which is seen as a reflection of ideas in people's life.

Another linguist of CDA is Norman Fairclough, who developed a three-dimensional framework to study discourse. His framework has the objective to concatenate the three dimensions into another analysis of languages in a text, such as analysis of the discourse practice where contains text production, distribution, and consumption, and analysis of discourse events. In other words, Fairclough mix the micro, mezzo, and macro-level of interpretation.

Thus, following those things, the researcher wants to connect the language, ideology, and power and the speakers of speech by analysing the speeches of Minister of Education and Culture 2019 and 2018, Nadiem Makarim and Muhadjir Effendy. The speeches are from the Teacher's Day speech in 2018 and 2019.

\section{Methodology}

This study uses a descriptive qualitative method to analyse the data. Litosseliti (2010) views that qualitative research involves both structures and patterns in analysing data without considering how many peculiar characteristics are needed. While descriptive research, according to Kothari (2004) idea is consisting of a survey and fact-finding. Using the descriptive qualitative method means that the researcher has no control over the data as well as the variable.

The researcher uses the three-dimensional framework by Norman Fairclough in analysing the data of Critical Discourse Analysis (CDA). The data are the written text or script of speeches from Nadiem Makarim and Muhadjir Effendy, which they performed on Teacher's Day. To collect the data, the researcher used some steps, including finding the script from https://batam.tribunnews.com/2019/11/23/beda-pidato-nadiem-makarim-dengan-muhadjir-effendy-di-hari-guru-nasional-takmau-janji-kosong. The second step was to read the script and the last step was to analyze the scripts used the three-dimensional framework by Norman Fairclough. 
In presenting as well as analyzing the data, the researchers used the qualitative data analysis theory from Miles and Huberman (1994) in Gani (2011). This kind of analysis has three steps in the process. They are data reduction, data display or data representation, and conclusion drawing and verification.

1. In the first step, which is data reduction, the data that has been obtained by observation is selected by the researchers in the set of classification to be analyzed. The analysis is to find what the micro, mezzo, and macro-level are in the speeches of Nadiem Makarim and Muhadjir Effendy and what the language is used in their speeches.

2. In the data display or representation, the researcher presented the data analysis in the table and used sentences to explain the data clearly.

3. Finally, in the last step, which is conclusion drawing and verification, the researcher concludes the result of analysis by using the researcher own words.

\section{Results and Discussion}

This study is made to find the Critical Discourse Analysis (CDA) in the speeches of Nadiem Makarim and Muhadjir Effendy. The researcher uses the three-dimensional framework from Norman Fairclough to analyse the data, which are the transcript of speeches from Nadiem Makarim and Muhadjir Effendy. Fairclough framework is an analysis of spoken or written language text as well as discourse practice and discursive events as of socio-cultural practice (Hussain et al., 2015). The three-dimensional framework from Fairclough are:

1. Micro-Level is analysing the text or script itself for the use of cohesion, coherence, grammar, theme, modality, and lexical structures. In other words, Hussain et al. (2015) define that the texts' syntax, metaphoric structure, and certain rhetorical devices are analysed at this micro-level.

2. Mezzo-Level is analysing the process of production, distribution, and use of the text. In addition, this level analyse the texts' production and consumption and focusing on how power relations are connected (Hussain et al., 2015).

3. Macro-Level is analysing the social context that affects the texts which consist of situational, institutional, and social levels. Karreman (2000) views that the micro-level contains the inter-textual understanding, trying to understand the social currents that affect the texts.

The data that have been found in the scripts are shown in these analyses:

\subsection{Micro Level}

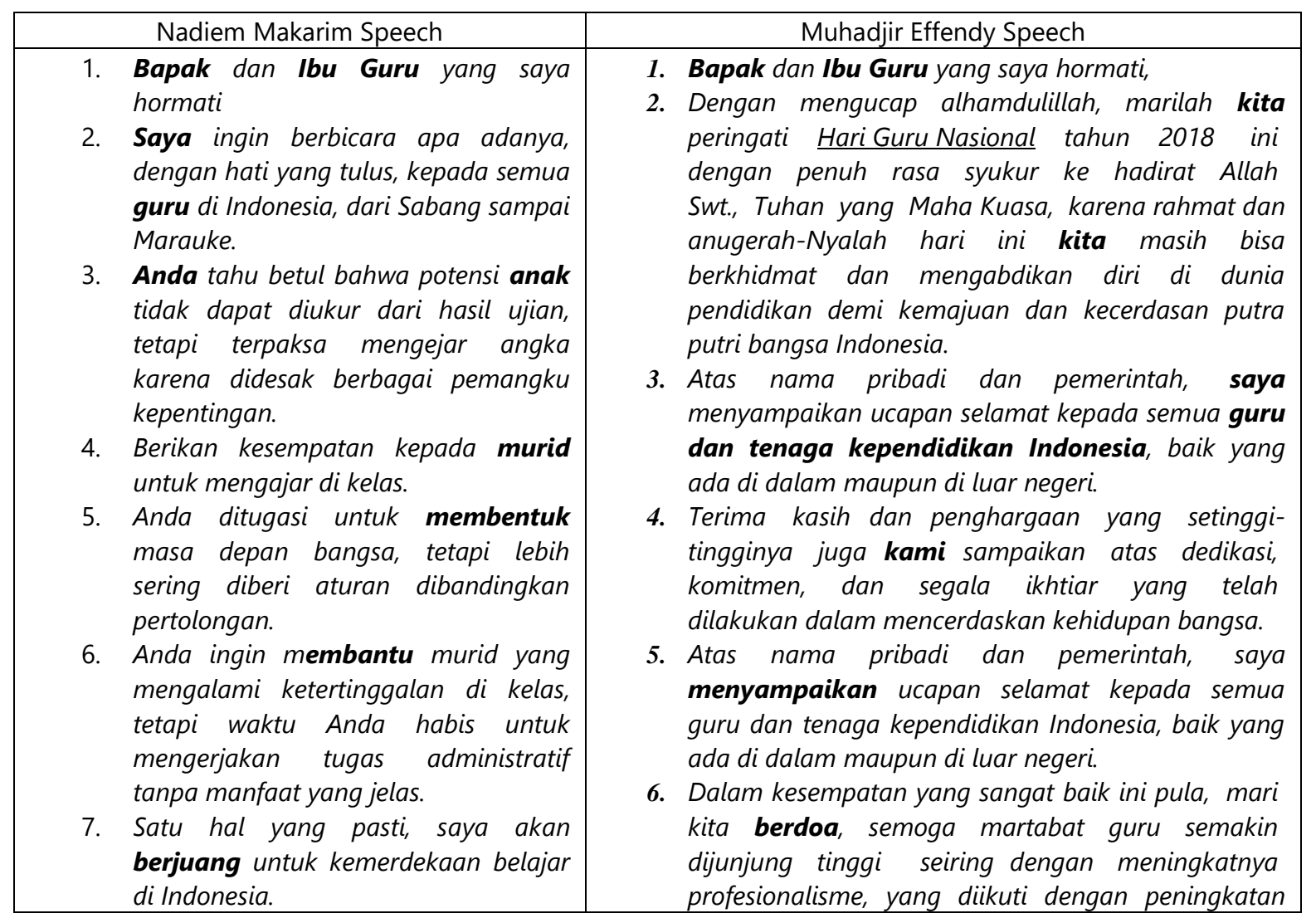


8. Anda frustasi karena Anda tahu bahwa di dunia nyata kemampuan berkarya dan berkolaborasi akan menentukan kesuksesan anak, bukan kemampuan menghafal.

9. Anda tahu bahwa anak memiliki kebutuhan berbeda, tetapi keseragaman telah mengalahkan keberagaman sebagai prinsip dasar birokrasi.

10. Anda ingin setiap murid terinspirasi, tetapi Anda tidak diberi kepercayaan untuk berinovasi. kesejahteraan, dan dedikasi dalam menjalankan tugas mulianya.

7. Dengan mengucap alhamdulillah, marilah kita peringati HariGuru Nasional tahun 2018 ini dengan penuh rasa syukur ke hadirat Allah Swt., Tuhan yang Maha Kuasa, karena rahmat dan anugerah-Nyalah hari ini kita masih bisa berkhidmat dan mengabdikan diri di dunia pendidikan demi kemajuan dan kecerdasan putra putri bangsa Indonesia.

- $\quad$ Nadiem Makarim Speech

In Nadiem Makarim speech, the researcher found the micro-level in such of linguistics aspects of the speech:

1. Bapak dan Ibu Guru yang saya hormati

2. Saya ingin berbicara apa adanya, dengan hati yang tulus, kepada semua guru di Indonesia, dari Sabang sampai Marauke.

3. Anda tahu betul bahwa potensi anak tidak dapat diukur dari hasil ujian, tetapi terpaksa mengejar angka karena didesak berbagai pemangku kepentingan.

4. Berikan kesempatan kepada murid untuk mengajar di kelas.

The words such as Bapak, Ibu Guru, Saya, guru, Anda, anak, and murid are the diction used to indicate the status of figures involved in the speech. Bapak, Ibu Guru, Anda are used to the formal greeting for special audiences, all teachers in Indonesia. The word saya is the pronoun I in English used by the speaker to call himself. In contrast, the words of anak and murid are used as the pronoun of students.

Nadiem Makarim separated the words for him using saya and Anda or Bapak, Ibu Guru as the peculiar listener of his speech. He never uses the word us for him and the teachers as the audience because he clearly stated in his speech that he wanted to talk sincerely with all teachers in Indonesia from Sabang to Merauke.

5. Anda ditugasi untuk membentuk masa depan bangsa, tetapi lebih sering diberi aturan dibandingkan pertolongan.

6. Anda ingin membantu murid yang mengalami ketertinggalan di kelas, tetapi waktu Anda habis untuk mengerjakan tugas administratif tanpa manfaat yang jelas.

7. Satu hal yang pasti, saya akan berjuang untuk kemerdekaan belajar di Indonesia.

The resource statements that Makarim uses are in the diction about something good. The words membentuk, membantu, berjuang were in English are to shape, help, and fight have positive meanings. In the dictionary, to shape is to give a peculiar form, help is to give assistance or support to someone, and the fight is to take part in struggling for something.

8. Anda frustasi karena Anda tahu bahwa di dunia nyata kemampuan berkarya dan berkolaborasi akan menentukan kesuksesan anak, bukan kemampuan menghafal.

9. Anda tahu bahwa anak memiliki kebutuhan berbeda, tetapi keseragaman telah mengalahkan keberagaman sebagai prinsip dasar birokrasi.

10. Anda ingin setiap murid terinspirasi, tetapi Anda tidak diberi kepercayaan untuk berinovasi.

The sentences in the above example of the data use conjunction such as karena (because) and tapi (but). These conjunctions make the sentences cohesive. The conjunction because in example 8, is subordinating conjunction which has a function to join the dependent clause into the main clause "karena Anda tahu bahwa di dunia nyata kemampuan berkarya dan berkolaborasi akan menentukan kesuksesan anak, bukan kemampuan menghafal." In example 9 and 10, use conjunction but which is coordinating conjunction with a function to join two sentences that are equal in grammatical.

- Muhadjir Effendy

In Muhadjir Effendy speech, the researcher found the micro-level in such of linguistics aspects of the speech:

1. Bapak dan Ibu Guru yang saya hormati, 
2. Dengan mengucap alhamdulillah, marilah kita peringati Hari Guru Nasional tahun 2018 ini dengan penuh rasa syukur ke hadirat Allah Swt., Tuhan yang Maha Kuasa, karena rahmat dan anugerahNyalah hari ini kita masih bisa berkhidmat dan mengabdikan diri di dunia pendidikan demi kemajuan dan kecerdasan putra putri bangsa Indonesia.

3. Atas nama pribadi dan pemerintah, saya menyampaikan ucapan selamat kepada semua guru dan tenaga kependidikan Indonesia, baik yang ada di dalam maupun di luar negeri.

4. Terima kasih dan penghargaan yang setinggi-tingginya juga kami sampaikan atas dedikasi, komitmen, dan segala ikhtiar yang telah dilakukan dalam mencerdaskan kehidupan bangsa.

The speaker used the words Bapak, Ibu Guru, saya, and guru the same as the used in the speech of Nadiem Makarim. In the speech of Muhadjir Effendy consists of many pronoun kita, kami which are our in English. The speaker used those words to say that he and the audiences who are teachers are unity. It can be said that he would struggle with the teachers in Indonesia by saying the word kita.

5. Dengan mengucap alhamdulillah, marilah kita peringati Hari Guru Nasional tahun 2018 ini dengan penuh rasa syukur ke hadirat Allah Swt., Tuhan yang Maha Kuasa, karena rahmat dan anugerahNyalah hari ini kita masih bisa berkhidmat dan mengabdikan diri di dunia pendidikan demi kemajuan dan kecerdasan putra putri bangsa Indonesia.

6. Hal ini meniscayakan peningkatan profesionalisme menyangkut sikap mental dan komitmen para guru untuk selalu meningkatkan kualitas agar memiliki kompetensi yang sesuai dengan perkembangan zaman.

The example in 5 shows that the sentence used karena (because) as the conjunction. Because is in the form of subordinating conjunction. The conjunction in example 6 is agar (so) that includes the form of coordinating conjunction.

\subsection{Mezo Level}

In the mezzo-level, it shows how the text is produced and used. The texts here are the transcript of speeches from Nadiem Makarim and Muhadjir Effendy. The speech of Nadiem Makarim was published by the Ministry of Education and Culture on 25 November 2019 while the speech of Muhadjir Effendy was published on 25 November 2018. Both Makarim and Effendy created each speech then their speeches were published publicly to the people of Indonesia by the Ministry of Education and Culture website. After being released, the speeches were usually used in the ceremony of Teacher's Day. The leader of the ceremony would read the text of the speech.

\subsection{Macro Level}

Macro-level consist of what the situational, institutional, and social levels are in the texts. The situational level in both texts or scripts of speeches from Nadiem Makarim and Muhadjir Effendy is on the special occasion of Teacher's day. As the Minister of Education and Culture, it is a must and a pivotal thing for them to give speeches in regards to the Teacher's day.

The institutional level of the speeches of Nadiem Makarim and Muhadjir Effendy is from them as the Minister of Education and Culture at their period and as the central government. The text of speeches should represent the speakers' ideas and should present resource persons from the experts who can review the content of the texts. Besides, after the speeches being read by Makarim and Effendy, many people from usual persons or experts give their opinion towards their speeches. They can criticize those speeches by giving positive or negative arguments.

The social level is that the speeches of Makarim and Effendy have certain motivations. Toward the ideas of Makarim's speech, the audiences gain positive motivation and agree with his opinions. Meanwhile, the audience reacted after listening to or reading the script of the speech from Effendy. Some people said that they disagree with his ideas since they were so complex and have no real evidence to improve education in Indonesia.

\subsection{Language used in the speeches of Nadiem Makarim and Muhadjir Effendi}

- Nadiem Makarim Speech

1. Selamat Hari Guru, \#merdekabelajar \#gurupenggerak

2. Mohon maaf, tetapi hari ini pidato saya akan sedikit berbeda. Saya ingin berbicara apa adanya, dengan hati yang tulus, kepada semua guru di Indonesia, dari Sabang sampai Marauke.

3. Saya tidak akan membuat janji-janji kosong kepada Anda. Perubahan adalah hal yang sulit dan penuh dengan ketidaknyamanan. Satu hal yang pasti, saya akan berjuang untuk kemerdekaan belajar di Indonesia. 
The language used in the speech of Nadiem Makarim was exactly what it is and the theme is also not widened everywhere. Makarim said that his speech was slightly different from the usual speech filled with inspirational and rhetorical words. Indeed his speech was real, like in example 2. Makarim's words in his speech went straight to the point and it could be said that it was like a poem with short or not using too long sentences. Nadiem Makarim himself wrote the speech. According to the Deputy Secretary-General of the Federation of Indonesian Teachers Unions (FGSI), the viral speech of Nadiem Makarim could touch the millennial generation, especially for teachers who needed to be more enthusiastic in innovating. The language used was a standard language but it was more creative and did not make the audience bored.

Nadiem Makarim has the mainstay words in his speech, namely \#merdekabelajar \#gurupenggerak, which are expected to arouse the teachers' enthusiasm in building a better Indonesian education. However, while other people gave a breakthrough as a promise for the development of education, Makarim stated in his speech clearly that he would not make empty promises and he added that he would fight for freedom of study in Indonesia as in example 3.

- Muhadjir Effendy Speech

1. Akhirnya, marilah kita jadikan Hari Guru Nasional ini sebagai semangat untuk terus membangun peradaban bangsa sehingga Indonesia menjadi bangsa yang berbudaya, cerdas, bermutu dan berkarakter, serta mampu bersaing dalam kancah pergaulan global.

2. Maka dari itu, marilah kita bergandeng tangan menunaikan tugas mulia ini.

The language used in the speech of Muhadjir Effendy was straightforward and rhetorical as speech in general by community leaders. However, the sentences were longer and the script reached four pages. The content of the speech discussed the teacher and its role and alluded to the industrial revolution and the characteristics of professional teachers. The language used was a standard language but a little boring.

In his speech, Effendy invited the teachers with him to develop Indonesian education, as in example 2. However, as far as his leadership period, words promised in his speech such as the Zoning System Policy did not get the result as expected.

\section{Conclusion}

The study wants to find out the Critical Discourse Analysis in the speeches of Nadiem Makarim and Muhadjir Effendy used the three-dimensional framework by Norman Fairclough. In his framework, three levels should be analysed to discover the critical discourse analysis. They are micro, mezzo, and macro-level. At the micro-level, the researcher found that both Makarim and Effendy used greeting such as Bapak, Ibu Guru, guru to their special audiences who are teachers in Indonesia. They use saya or I to call themselves. In the speech of Muhadjir Effendy, he used words like kita, kami or our to represent him and the audiences. In the speeches of Makarim and Effendy, both used conjunction to show cohesion in their sentences. There are conjunctions such as because and but in Makarim's speech and in the Effendy's speech used conjunction like because and so. Mezzo-level illustrates the production of the texts where here are the transcript or written text of speeches by Nadiem Makarim and Muhadjir Effendy which published on 25 November 2019 for Makarim speech and 2018 for Effendy speech by the Ministry of Education and Culture in their websites. The published speeches then being used in the ceremony of Teacher's Day. The last is macro-level which shows the situational, institutional, and social levels of the texts. Both speeches of Nadiem Makarim and Muhadjir Effendy are made regarding the ceremony of Teacher's Day and it shows the situational level. In institutional level demonstrates that the speeches are from Makarim and Effendy as the Minister of Education and Culture in their period time. The social level shows that the speeches from Makarim and Effendy got their positive and negative reactions from the audiences, not only teachers but also all Indonesian people. The language used by Nadiem Makarim and Muhadjir Effendy is a standard language, but Makarim's speech was more creative, while Effendy's speech was making the audience get bored.

Funding: This research received no external funding

Conflicts of Interest: The authors declare no conflict of interest.

\section{References}

[1] Bukhari \& Xiaoyang, W. (2013). Critical discourse analysis and educational research. Journal of Research \& Method in Education, 3(1). Pp. 917. Retrieved from www.iosrjournals.org

[2] Farrelly, M. (2010) .Critical discourse analysis in political studies: an illustrative analysis of the 'empowerment' agenda. Politics, 30(2). Pp. 98104

[3] Hasibuan., H., K. (2018). A critical discourse analysis on state address of president jokowi. Retrieved from http://repositori.usu.ac.id/handle/123456789/7308

[4] Hussain, S., Jote, A. \& Sajid, S. (2015). Critical discourse analysis: demystifying the fuzziness. The International Journal Of Humanities \& Social Studies, 3(10), 242-249

[5] ledema, R. (2004). Critical Discourse Analysis and Cognitive Linguistics, by Kieran O'Halloran; 280 pp., Edinburgh University Press, 2003, ISBN 0748618287 (paperback). Linguistics and Education, 15(4), 413-423. doi:10.1016/j.linged.2005.01.003 
[6] Leitch., S. \& Palmer., I. (2010). Analysing texts in context: current practices and new protocols for critical discourse analysis in organization studies. Journal of Management Studies. 47(6). doi: 10.1111/j.1467-6486.2009.00884.x

[7] Liu, K., \& Guo, F. (2016). A review on critical discourse analysis. Theory and Practice in Language Studies, 6(5). 1076-1084. DOI: http://dx.doi.org/10.17507/tpls.0605.23

[8] Kusumawati, A., J. (2011). A discourse analysis of sby's international speech text: a study on critical linguistics. Journal of English and Education, 5(1), 1-28

[9] Luke, A. (1995). Chapter 1: Text and Discourse in Education: An Introduction to Critical Discourse Analysis. Review of Research in Education, 21(1), 3-48. doi:10.3102/0091732x021001003

[10] Priatmoko, F., X., N., A. (2013). Critical discourse analysis of susilo bambang yudhoyono's speech

[11] Putra., H., P. \& Triyono., S. (2018). Critical discourse analysis on kompas.com news: gerakan \#2019gantipresiden. Leksema Jurnal Bahasa dan sastra, 3(2), 1-9

[12] Ramanathan, R. \& Hoon, T., B. (2015). Application of critical discourse analysis in media discourse studies. 3L: The Southeast Asian Journal of English Language Studies. 21(2), 57-68

[13] Rohmah, S., N. (2018). Critical discourse analysis of donald $j$ trump's speeches

[14] Triyono., S. \& Liambo., E., Y. (). Ideology in translating news headline: a critical discourse analysis point of view. Advances in Social Science, Education and Humanities Research. 165. Pp. 1-5. Retrieved from http://creativecommons.org/licenses/by-nc/4.0/

[15] Sahfitri., D., I. (2019). A critical discourse analysis of the prime minister jacinda ardern's address of christchurch mosque accident.

[16] Sharififar, M. \& Rahimi, E. (2015). Critical discourse analysis of political speeches: a case study of obama's and rouhani's speeches at un. Theory and Practice in Language Studies. 5(2). Pp. 343-349. DOI: http://dx.doi.org/10.17507/tpls.0502.14

[17] Ulinnuha, R., Udasmoro, W. \& Wijaya, Y. (2013). Critical discourse analysis: theory and method in social and literary framework. Indonesian Journal of Applied Linguistic., 2(2), 262-274

[18] Wang, J. (2010). A critical discourse analysis of barack obama's speeches. Journal of Language Teaching and Research, 1(3), $254-261$. DOI:10.4304/jltr.1.3.254-261 